\title{
The potential of timber-based buildings in terms of energy efficiency
}

\author{
Jozef Švajlenka ${ }^{1, *}$, Mária Kozlovská ${ }^{1}$ \\ ${ }^{1}$ Technical University of Košice, Faculty of Civil Engineering, Department of Construction \\ Technology, Economy and Management, Vysokoškolská 4, 04001 Košice, Slovakia
}

\begin{abstract}
The topic of energy efficiency is currently under discussion. One of the areas of energy efficiency is the energy efficiency of buildings. The thermo-technical requirements for building envelope structures are gaining increasing importance due to new legislation and technical regulations regarding the reduction of heating and energy demands of buildings over time and because of continuously increasing energy prices. Building construction and the operational costs of buildings are among the largest consumers of material and energy resources and environmental pollutants. Ecological constructions are a response to the current state of the environment. A suitable solution that represents ecological construction, operation and comfortable living is the construction of lowenergy and passive houses based on wood. Wood-based buildings have many benefits that are particularly timely in the context of sustainability today. The aim of this paper is to introduce selected aspects of wood-based buildings in the context of energy efficiency and thus to reduce the adverse effects of construction on the surrounding environment.
\end{abstract}

\section{Introduction}

The European Union is now paying more attention to the issue of overall energy savings. Buildings have an impact on long-term energy consumption [1], and the residential building and tertiary sector, the main part of which is buildings, accounts for more than $40 \%$ of the total energy consumption in the community and in Slovakia. The reduction of energy consumption and the use of renewable energy [2] in the building sector are therefore important measures needed to reduce energy dependency and greenhouse gas emissions. This creates the preconditions for achieving the set of energy efficiency targets. In the area of buildings, these objectives are followed by the requirements of the directive no. 2010/31 / EU on the energy performance of buildings in which new requirements for the construction of new buildings are stipulated to ensure that all new buildings constructed after 2020 are nearly zero-energy buildings. For new buildings which are owned and operated by public authorities, there has been a requirement for buildings to have almost zero energy consumption since 2018 [3].

*Corresponding author: jozef.svajlenka@tuke.sk 
As of 1 January 2013, new legal and technical regulations have come into force, which have had an impact increasing demands for energy savings for heating and thus increasing the demand for heat for heating and cooling. These requirements are not only stricter for new buildings, but also for significantly renovated buildings. The proposed measures are to meet the hygiene and energy requirements laid down in STN 73 0540-2: 2012. The properties of the built-in components influence the calculated thermal and technical properties of the building structures. The correlation of the actual properties with those that are proposed depends on the accuracy of the properties of the components, their technical quality and the quality of installation. The design values of building materials (products) are given in STN 73 0540-3: 2012 [4].

Within the European area, directive 2010/31 / EU of the European Parliament and of the council of 19 May 2010 on the energy performance of buildings refers to increasing energy savings. Individual EU Member States are obliged to incorporate this directive into their legal systems by a predetermined date. However, not all EU countries are doing well. Therefore, in the near future we can expect increasing demands concerning the thermal insulation properties of buildings. This trend is necessary to maintain the much-discussed energy independence. Even at the individual level, the solution can be a low-energy, passive energy or zero-standard construction. The construction of such a family house compared to a house built of classic building materials costs on average 10 to $25 \%$ more depending on the level of energy intensity. The return on investment in the construction of an energy-efficient construction takes from 8 to 15 years, depending on the selected technology. The amount of energy consumption is given in $\mathrm{kW}$ per unit of time, usually an hour. The largest expense regarding energy consumption in a family house is heating (up to $80 \%$ ). This is because in Slovakia, the average heat is 6-8 months a year. Therefore, it is necessary to focus on solutions aimed at reducing thermal bridges (heat leakage) during construction. Anyone who plans to save on energy costs and has no problem with financial coverage should think about construction strategies that provide higher thermal insulation properties. Over the last few years, the demand for the construction of low-energy and passive houses has been increasing [5]. People are aware of the unstoppable trend of rising energy prices. This is also why we are seeing increasing interest in reducing household energy consumption. Emphasis is placed on the right choice of building system with excellent thermal insulation properties and the selection of suitable technologies such as heat recovery units, heat pumps, solar collectors and others [6].

\section{Material and methods}

The operation and use of buildings plays an important role in their life cycle in terms of both energy and financial resources. Real wood-based buildings were the subjects of investigation in terms of operating costs incurred during building operation. The most frequently used wood-based construction systems represented in our Central European region are: column construction systems, log construction systems and prefab panel construction systems made of whole-wall sandwich panels. For a better understanding of the differences between the individual wood-based construction systems, the basic characteristics of the examined timber construction systems are presented below. The data collected on the works concerned, in particular, the basic technical characteristics of the individual works and the operating costs incurred by users during their use. In total, fiftyseven real-life buildings were included in the analysis. Buildings were divided according to the above-mentioned construction systems and also according to energy standards. The data obtained from the analysed buildings were subjected to statistical analysis using both descriptive statistical methods and correlation analysis to determine the correlation 
dependencies in accordance with the stated research objective. Statistical analysis was performed using STATISTICA 12 software [16].

\subsection{Column construction system}

Column structures were developed in the USA and Canada. Their emergence was prompted by the Industrial Revolution, which made it possible to produce both large quantities of sawn timber of the same dimensions and cheap nails of standard dimensions and properties. In the US original two-by-four system, there were more or less only two dimensions of timber were used $-2 \times 4$ " (about $50 \times 100 \mathrm{~mm}$ ) lumber used for posts and $2 \times 8$ " (about 50 $\times 200 \mathrm{~mm}$ ) planks used as horizontal lintels, joists and rafters with the axial distance of the supporting elements being 400 to $600 \mathrm{~mm}$. In our country, columns with a cross section of 50 to $60 \mathrm{~mm} \times 120$ to $160 \mathrm{~mm}$ are currently used (especially where there is a need for a greater thickness of thermal insulation ). If timber houses need to meet the requirements for thermal insulation properties, even in the case of the more demanding construction of passive houses, posts made of natural wood must be replaced by thin-walled beams $[7,8]$. The spatial stability of columnar constructions is usually ensured by cladding with agglomerated large-area materials. If the post is not suitable from a static point of view, the necessary profiles are created by associating or creating a sectioned or composite cross section. In order to increase the fire safety of pillar structures, internal plasterboard linings are mostly used. Column constructions do not require any heavy mechanization during assembly. Their disadvantage is that the entire production takes place directly at the construction site. This can be lengthy in more complex constructions and, moreover, the structure is exposed to inclement weather during assembly, which can negatively affect its properties. To speed up assembly on site, some work activities can be transferred to the workshop (for example, sawing wooden elements to the final dimension). As with log buildings, it is necessary to ensure that the structure is in contact with the foundations. Considerable damage can also be caused by the inadequate installation of a vapour barrier and external cladding or covering [9-11].

\subsection{Log construction system}

The construction of modern log cabins consists of construction elements made of either solid wood (so-called Canadian log cabins) or glued wood - glued blocks. Massive construction elements can be prepared by hand as is the case with traditional logs or profiled using machines. Individual lengths may be in one piece or connected lengthwise through the use of different types of joints. The non-edged log elements are most often made from logs of freshly cut trees of high humidity but may be partially or fully dried before the individual wall elements are made. Modern timber structures made of glued wood (so-called prefabricated timber) are technically state-of-the-art. The glued log elements are made by gluing together several parts. Bonding is performed along the width, height and length of the element. The glued elements have different dimensions and crosssectional shapes. The transverse profile may be square, rectangular or circular (glued blanks that match the natural roundness of the logs from the outside). The production of glued timber elements is more demanding and economically more expensive than solid timber elements. However, they have their advantages, with certain glued elements such as the availability of quality wood, the dimensional stability of the element, the aesthetics of logs without cracks on their exterior and interior sides, the improvement of thermal-technical properties of the log wall itself. The horizontal joint seal is similar to those used in solid timber construction $[9,10,12]$. 


\subsection{Prefab panel construction system}

At present, the panel building system is the most widespread strategy for the construction of wood-based buildings. The basis of the construction of the panels is a wooden frame roughly covered with suitable large-area materials. The wooden frame of the panel is structurally adapted to the function it performs - perimeter, ceiling, roof, floor. The frame structure and dimensions are adapted to the different functions. The space between the ribs is filled with thermal sound insulation. For sheathing particle boards, OSB boards, gypsum boards, cement-bonded boards and similar are used. Panels can be manufactured with a variety of finishes, from thick frames clad on one side with large-area material to panels with built-in windows and doors, and panels with finished interior and exterior and with built-in wiring. The main advantage of the construction of the panel system is the possibility of maximum preparation of the building in production and the quick assembly and completion of the building on the construction site. The panels can also be of a variety of sizes - from $1.200 \times 2.600 \mathrm{~mm}$ panels weighing up to $80 \mathrm{~kg}$, which do not require heavy mechanization to whole wall panels up to $12 \mathrm{~m}$ long, requiring heavy mechanics for transportation and assembly. The correct joining of the panels together with the anchoring of the panels to the substructure is important $[9,13]$.

\section{Results and discussion}

In terms of operating costs, heating costs were analysed, which in general account for 58\% - $67 \%$ of total operating costs on average $[14,15]$. Although all the operating costs were sought from the respondents, most respondents reported only the heating costs.

Based on the above-mentioned facts, we have focused on the analysis of the operating costs of heating. We did not deal with other costs in more detail because the users of construction sites could not clearly define exact details of all construction operation costs. Additionally, other operating costs are mainly related to the manner of use and the number of people using the construction. For these reasons, the analysis focused only on the operating costs of heating. Table 1 summarises the average observed operating costs of heating, calculated per $\mathrm{m} 2$ of the usable area of individual buildings divided into construction systems and taking into account the energy standard of buildings.

Table 1. Analysis of heating costs of the compared construction systems of wooden buildings

\begin{tabular}{|c|c|c|}
\hline $\begin{array}{l}\text { Construction } \\
\text { system }\end{array}$ & Energy standard (number of buildings)* & $\begin{array}{c}\text { Average heating costs } \\
\text { (EUR) per } \mathrm{m}^{2} \text { of usable } \\
\text { area }\end{array}$ \\
\hline \multirow{4}{*}{$\begin{array}{c}\text { Prefab panel } \\
\text { construction } \\
\text { system }\end{array}$} & Energy efficient $(80 ., 4-150 \mathrm{kWh} / \mathrm{m} 2 . \mathrm{a})(6)$ & 0.448 \\
\hline & Low-energy house $(40.7-80.4$ kWh/m2.a) (8) & 0.308 \\
\hline & $\begin{array}{l}\text { Ultra low-energy house }(20.4-40.7 \mathrm{kWh} / \mathrm{m} 2 . \mathrm{a}) \\
(6)\end{array}$ & 0.364 \\
\hline & $\begin{array}{c}\text { Passive house (specific heat / cooling demand } \\
\text { (MPT) } \max 20.4 \mathrm{kWh} / \mathrm{m} 2 . \mathrm{a})(2)\end{array}$ & 0.304 \\
\hline \multirow{5}{*}{$\begin{array}{c}\text { Column } \\
\text { construction } \\
\text { system }\end{array}$} & $\begin{array}{l}\text { Buildings not meeting STN (up to } 150 \\
\mathrm{kWh} / \mathrm{m} 2 . \mathrm{a})(2)\end{array}$ & 0.868 \\
\hline & Energy efficient $(80.4-150 \mathrm{kWh} / \mathrm{m} 2 . \mathrm{a})(5)$ & 0.575 \\
\hline & Low-energy house $(40.7-80.4 \mathrm{kWh} / \mathrm{m} 2 . \mathrm{a})(5)$ & 0.311 \\
\hline & $\begin{array}{c}\text { Ultra low-energy house }(20.4-40.7 \mathrm{kWh} / \mathrm{m} 2 . \mathrm{a}) \\
(3)\end{array}$ & 0.366 \\
\hline & $\begin{array}{c}\text { Passive house (specific heat / cooling demand } \\
\text { (MPT) max } 20.4 \mathrm{kWh} / \mathrm{m} 2 . \mathrm{a})(4)\end{array}$ & 0.212 \\
\hline
\end{tabular}




\begin{tabular}{ccc}
\hline \multirow{2}{*}{$\begin{array}{c}\text { Log } \\
\text { construction } \\
\text { system }\end{array}$} & Energy efficient $(80.4-150 \mathrm{kWh} / \mathrm{m} 2 . \mathrm{a})(6)$ & 0.690 \\
\cline { 2 - 3 } & Low-energy house $(40.7-80.4 \mathrm{kWh} / \mathrm{m} 2 . \mathrm{a})(7)$ & 0.406 \\
\cline { 2 - 3 } & Ultra low-energy house $(20.4-40.7 \mathrm{kWh} / \mathrm{m} 2 . \mathrm{a})$ & 0.307 \\
\hline
\end{tabular}

Notes: *[17]

Through correlational analysis at the level of significance of $\mathrm{p}<0.05$, we found a statistically significant effect of the energy standard of buildings on the level of operating costs of heating $(\mathrm{P}=-0.4243)$. This implies that there is a reduction in the operating costs of heating caused by increasing the energy standard of the building, which is also a prerequisite for making buildings more efficient. The findings from Table 1 confirmed the assumption of a reduction in the operating costs of heating by increasing the energy standard of the building. In terms of usable area of the building $\left(\mathrm{m}^{2}\right)$, we recorded the lowest values for the panel construction system in almost all energy classes except for the passive standard where the column construction system prevailed. This difference is also attributed to the fact that the panel construction system did not obtain a larger number of buildings in the passive standard of construction compared to the column construction system. A passive standard in the assessment of timber structures has not been recorded. By comparing the construction systems with each other in terms of operating costs, the pillar construction system seems to be the most effective variant, with the panel construction system being only slightly behind. In terms of the efficiency of the financial resources, it can be concluded from the findings that the log construction system was not as economical as the other considered construction systems.

\section{Conclusion}

In terms of sustainability, wood-based buildings are undoubtedly an ecological alternative to construction. However, information about them is still little known in some regions. The aim of this article was to present findings from the analysis of real-life constructions in the context of operating costs incurred during the use of such constructions. Based on the correlational analysis of the obtained data, we found a statistically significant impact between the energy standard of buildings and the operating costs incurred during their operation. With regard to structural systems, post and panel structural systems seem to be effective variants in comparison to the log construction system. The findings of this analysis of real-life constructions can serve both the users and contractors as well as potential investors when considering what construction system and energy standard to choose when purchasing a particular wood-based construction. Since the trend of decreasing the energy balance of buildings is irreversible, everyone should remember that by choosing efficient and sustainable solutions, it is possible to manage energy and financial resources more efficiently, and especially to reduce negative impact on the environment.

Acknowledgement: VEGA project-1/0557/18 "Research and development of process and product innovations of modern methods of construction in the context of the Industry 4.0 principles". 


\section{References}

1. J. Gašparík, S. Szalayová, B. Alamro, M. Gašparík, Proceedings of the 3rd International Conference on Engineering Sciences and Technologies, (2019)

2. N. Antošová, B. Belániová, B. Chamulová, K. Janušová, J. Takács, Proceedings of the $3 r d$ International Conference on Engineering Sciences and Technologies, ESaT 2018, (2019)

3. Koncepcia energetickej hospodárnosti budov do roku 2010 s výhl'adom do roku 2020 (2014)

4. http://www.izola.sk/store/file/Revidovan\%C3\%A1\%20tepelnotechnick\%C3\%A1\%20n orma\%20STN\%2073\%200540.pdf (2014)

5. T. Hrdlicka, M. Cupal, International Multidisciplinary Scientific GeoConference Surveying Geology and Mining Ecology Management (2019)

6. http://www.woodbuilding.sk/?page_id=204 (2020)

7. V. Kaputa, M. Olšiaková, H. Mat’ová, E. Drličková, Digitalisation and Circular Economy: Forestry and Forestry Based Industry Implications - Proceedings of Scientific Papers, (2019)

8. V. Gregorová, M. Ďubek, S. Ďubek, Z. Štefunková, IOP Conf. Series: Mat. Sci. \& Eng (2019)

9. V. De Araujo, J. Barbosa, M. Gava, J. Garcia, A. Souza, A. Savi, E. Morales, J. Molina, J. Vasconcelos, A. Christoforo, L.F. Rocco BioResources 11, 7889-7901 (2016)

10. J. Paulo Cruz, Structures and Architecture: New concepts, applications and challenges. CRC Press, (2013)

11. T. C. Marcin Forest, Prod. J. 37 (7/8), 55-61 (1987)

12. P. Lavoie, Green building trends are advancing wood as a building material. Wood Market Trends in Europe (Vancouver 2008)

13. M. Marchesi, I. A. Ferrarato, Procedia CIRP 34, 199-205 (2015).

14. J. Štefko, et al., Moderné drevostavby, (Bratislava 2010)

15. http://stavba.tzb-info.cz/pasivni-domy/8238-ekonomicke-porovnani-provozupasivniho-domu-a-bezne-vystavby (2020)

16. StatSoft, Inc., STATISTICA 12 (data analysis software system), version 12. www.statsoft.com.

17. STN 730540 (2002) 